\title{
Incentives for Promoting Innovation in Engineering
}

\author{
Tatyana Odinokova* \\ ISMA University, 1 Lomonosova Str., Bld.6, LV-1019, Riga, Latvia
}

\begin{abstract}
Engineering is a major industry in Latvian economy. It ranks third (to wood processing and food industry) in the amount of turnover. Due to the inflow of foreign investment, well-educated labor as well as export potential, engineering and metalworking have a promising outlook. However, this industry lacks competitiveness due to cutting investment and development expenses in this sector, as well as low added value. That said, the government should step up its policies to promote innovation activity of machinery manufacturers.
\end{abstract}

\section{Introduction}

The development of production industry, engineering and metalworking in particular, is an important tool to enable Latvian economy achieve a higher level. The formation of Latvian production industry started in the mid19th century. It was due to a number of factors, namely, a favorable geographical position, a developed port and railroad infrastructure, and the availability of well-educated labor. Latvian production industry has gone through several stages of development related to historic processes. At the first stage, heavy industry machinery engineering and metalworking in particular, prevailed in the production industry. In 1991, when Latvia became an independent nation, industrial production plummeted dramatically. This collapse was due to a low competitive ability in the free market environment. Some industries, such as food industry and wood processing, which traditionally relied on local raw material, suffered less and retained their dominant position. Engineering and metalworking, however, faced significant problems, because they relied on imported raw materials and market outlets. This led to the drive for assimilation of western technologies and marketing.

Until the end of 2008, engineering and metalworking had been among the highest growth industries in Latvian economy, with the annual growth of $20 \%$. Such rapid growth rate was due to the expansion of the market as well as production modernization. Expansion of the market was caused by an increasing demand at the local market as well as a proactive development of foreign markets. Assimilation of new technologies in 2004-2005 was partly funded by the EU. The situation in the engineering industry changed dramatically in 2009 ,

${ }^{*}$ Corresponding author:: tatjana.odinokova@isma.lv 
when production fell by nearly $40 \%$. The negative trend affected not only Latvia but the other European economies as well, which was the outcome of the global economic crisis. The factors that caused the drop of production in the engineering industry include:

- a fall in the demand for investment goods in other industries;

- a decrease of production in related industries in foreign markets;

- a sharp drop in the demand in the local market, in the construction industry in particular.

Adverse processes prevailed in 2009 and in early 2010. In 2010, however, the situation became stable, with a further growth of production, which reached 30\% in 2010 and 2011. As a result, the industry restored its pre-crisis level. In 2012 production exceeded its precrisis level and reached its highest both in output and in export. In 2013, however, Liepājasmetalurgs froze its business, while in 2014 export to Russia shrank, which led to a decrease in production [1].

The industries that dominate the Latvian economy now are wood processing and food industry, followed by engineering, metalworking and chemical industry. It should be noted that in 2016, engineering and metalworking accounted for $17 \%$ of the total turnover in the manufacturing industry and $21 \%$ of the total export value, ranking third in the Latvian economy. By way of comparison, the turnover in the leading industries, namely, wood processing and food industry, amounted to $28 \%$ and $23 \%$, respectively. In terms of employment figures, engineering and metalworking account for $19 \%$, very close to the food industry $(20 \%)$ and a little lower than wood processing $(21 \%)$. In terms of export potential, however, it ranks second (21\%) to wood processing (32\%) [2]. In monetary terms, the value of exported goods produced by the engineering industry reached 0.9 billion euros in 2017 . Nearly four fifths of the total output of the engineering and metalworking industry is exported to over 100 countries. $74 \%$ of this industry's output are exported to the European Union. In 2017, Denmark, Sweden, Germany, Russia, the UK, Norway and France were the major trading partners of Latvian engineering and metalworking enterprises. As an example, $16 \%$ of the output of Latvia's engineering industry was exported to Denmark, $13 \%$ - to Sweden, and $11 \%$ to Germany. Export figures have proved that the goods produced in this industry are competitive in terms of prices, quality and delivery dates.

The experience of several economies has shown that investment into scientific research is vital for the development of engineering [3-5]. Therefore, Latvian experts have developed "2014 - 2020 National Development Plan", which provides for the investment of $1.5 \%$ of the GDP into research and technology development. However, the real life situation has shown that over the period between 2014 and 2016 the level of investment went down from $0.69 \%$ to $0.44 \%$ of the GDP [2]. For comparison, the average figure in the European Union is 2\% of the GDP and around 3\% in Sweden and Germany. Moreover, it should be noted that in the EU, a large portion of investment comes from the private sector, while in Latvia research and development is funded by the state. This lag is a factor that hinders innovation development in Latvia.

According to the latest European Innovation Scoreboard (EIS) data, Latvia has remained a Moderate Innovator [6].By analyzing Latvian statistics data, one can assess the situation in terms of innovative activity of industrial enterprises, including engineering enterprises.

In 2001-2002 there were 516 innovation-active enterprises introducing technological innovations. By 2006-2008 the number of such enterprises reached its peak of 707 enterprises. The 2008 crisis hindered the activity of the companies working in this industry. Latvia had failed to overcome the consequences of the crisis by 2014, when the number did not exceed 375 innovation active enterprises. Figure 1 shows the ratio of innovation active enterprises introducing technological innovations against the total number of enterprises. 


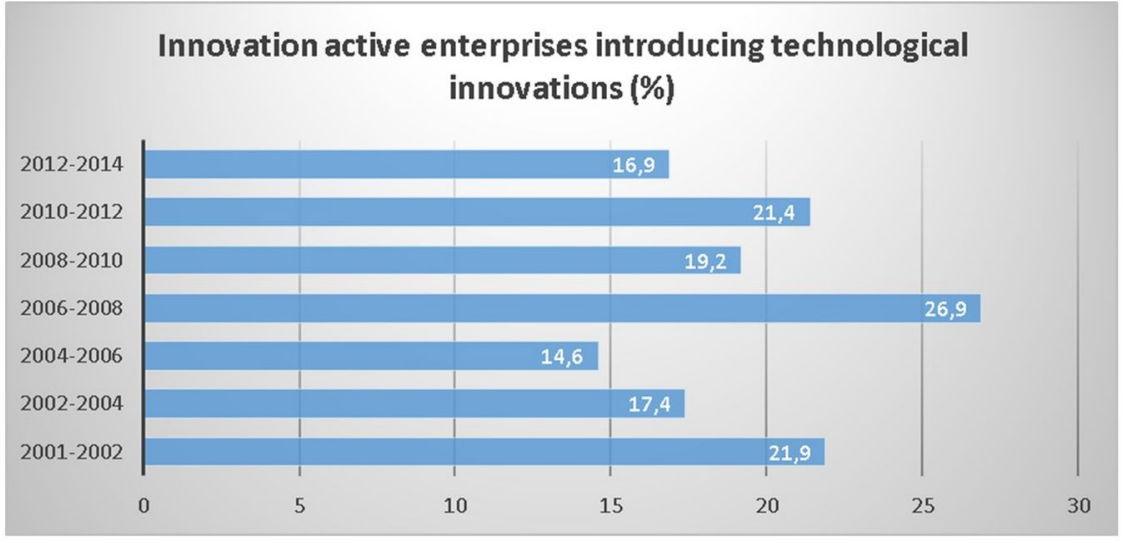

Fig.1. Innovation active enterprises introducing technological innovations (\%)[7]

Information represented in Figure 1 suggests that there have been sharp fluctuations in the innovation activity of Latvian enterprises over the past period. By 2014 their number had shrunk by $10 \%$ when compared to the pre-crisis period, which suggests that Latvian economy has not fully recovered. This means that measures are needed to promote innovation activity of the production industry and engineering enterprises in particular. Such activities stimulate the innovation of the entire economy $[4,5]$

Another aspect to point out is total expenditure on technological innovation. Total expenditure has been growing since 2004. As an example, in 2004 total expenditure amounted to $56.5 \mathrm{~m}$ euros compared to $299 \mathrm{~m}$ in 2008. The crisis brought about a sharp decrease in expenditure - $66.9 \mathrm{~m}$ euros in 2010. In 2012 expenditure on technological innovation reached a peak of $337.1 \mathrm{~m}$ euros but dropped to $108.2 \mathrm{~m}$ euros in 2014. [7]

R\&D expenditure by source of funding has remained a major issue in the study of innovation activity. Statistical data have shown that overall R\&D expenditure in 2015 reached $152.2 \mathrm{~m}$ euros, compared to $109.6 \mathrm{~m}$ euros in 2010. In 2016, however, there was a sharp drop to $110.4 \mathrm{~m}$ euros. At the same time, $\mathrm{R} \& \mathrm{D}$ expenditure in the business enterprise sector shrank as well. In 2010 they invested $42.5 \mathrm{~m}$ euros, in 2015 investment dropped to $30.5 \mathrm{~m}$ euros, while in 2016 the amount went down again to just $23.8 \mathrm{~m}$ euros. Investment by the Government, on the other hand, increased - $28.9 \mathrm{~m}$ euros in $2010,49.8 \mathrm{~m}$ euros in 2015, and $52.7 \mathrm{~m}$ euros in 2016. Increased government $\mathrm{R} \& \mathrm{D}$ expenditure provided the opportunity to offset the losses caused by the shrinkage of private sector expenditure. It should be noted, that such processes are not typical for most EU economies, where the entrepreneurial sector is the main source of $R \& D$ funding. There was also a slight increase in $R \& D$ expenditure on higher educational institutions $-1.6 \mathrm{~m}$ euros in $2010,3.4 \mathrm{~m}$ euros in 2015 , and $3.2 \mathrm{~m}$ euros in 2016. The last investments came from abroad. Statistical data have shown that compared to 2010 , they nearly doubled in 2015 , from $36.6 \mathrm{~m}$ euros to 68.5 $\mathrm{m}$ euros. In 2016, however, they dropped sharply to $30.7 \mathrm{~m}$ euros. This information provides grounds for a conclusion that the sources of R\&D funding have been reallocated. Along with an increased weight of the government sector and the sector of higher educational institutions, the impact of the entrepreneurial sector and foreign investors has diminished.

The key index of innovation activity is total expenditure on technological innovation. Detailed information on the total expenditure on technological innovation for 2014 is represented in Table 1[7]. 
Table 1.Expenditure on technological innovation, 2014 ( $\mathrm{mln}$ euros)

\begin{tabular}{|l|c|c|c|c|}
\hline \multirow{2}{*}{ Expenditure on technological innovation } & \multirow{2}{*}{ Total } & By number & \multicolumn{2}{|c|}{ Of employees } \\
\cline { 3 - 5 } & & $\mathbf{1 0 - 4 9}$ & $\mathbf{5 0 - 2 4 9}$ & $\geq \mathbf{2 5 0}$ \\
\hline Industry & 108.2 & 20.9 & 53.4 & 33,9 \\
\hline Intramural R\&D & 13.6 & 1.9 & 5.6 & 6.1 \\
\hline Extramural R\&D & 5.0 & 0.4 & 1.0 & 3.6 \\
\hline Acquisition of machinery and equipment & 82.6 & 13.4 & 45.7 & 23.5 \\
\hline Expenditure for other innovation activities & 7.0 & 5.2 & 1.1 & 0.7 \\
\hline
\end{tabular}

Statistical data have shown that medium size enterprises with $50-240$ employees are the biggest investors into technological innovations. Paradoxical as it may seem, Latvia's large companies with over 250 employees and a better financial opportunity, are less innovation active. Small enterprises often face financial problems and invest the least. In Latvia domestic investment into technological innovation exceeds foreign investment. This is a positive development because it is indicative of positive processes in the Latvian economy, in particular, of the availability of accumulated resources to enhance innovation activity [8]. On the other hand, a decrease in foreign investment is the evidence of a loss of interest to this process on the part of foreign investors. It is worth mentioning, that this situation is typical for Latvian economy in general.

Another index to consider is innovation active enterprises by type of innovation over the period 2012 - 2014. The share of innovation active enterprises introducing product, process, unfinished, suspended and/or abandoned innovations, was 7.1\%. Besides the above mentioned innovations, $9.9 \%$ of enterprises also introduced organizational and/or marketing innovations. Most enterprises (11.2\%) only introduced organizational and/or marketing innovations [7]. This information provides a reason for the conclusion that enterprises are more interested in the investment into organizational and/or marketing innovation than new products and processes. Start-ups are an exception in this process, but their importance is steadily growing [9-12].

The final aspect is the total number of innovation active enterprises in the production industry. Over the period 2012 - 2014 innovation active enterprises in the production sector accounted for $28.2 \%$ of the total number. Consequently, $71.8 \%$ were innovation inactive [7]. This information shows that at present, the majority of engineering enterprises, which are part of the production sector of economy, are innovatively inactive. This brings up the legitimate question of what methods are used in Latvia to promote innovation activity. The experience of a number of economies has shown that it is the forms and methods used for encouraging innovation activity that cause it to increase or decrease. Scientific research and innovative management methods are of great importance in this proces [13,14].

There are direct and indirect methods which are used in the developed economies. Among the direct methods are project funding by the government, provision of preferential loans, and government procurement of innovative products. Some of the indirect methods are fiscal incentives, creation of business incubators, and industry clusters. Indirect methods aim to bring in private investments into innovation processes. The analysis of the previously reviewed information suggests a conclusion that direct methods to promote innovation in Latvia are in active use now. The government is increasing investment into $\mathrm{R} \& \mathrm{D}$ in the production industry, which is the evidence of its determination to pursue a proactive innovation policy. However, indirect promoting methods are more common, and we will review them in more detail.

The first area of focus are technology parks. Latvia's technology parks implement, cooperate and coordinate EU funded projects. As an example, Latvia took part in the 
projects under the fifth EU Framework Program for Research and Technological Development, project EC IRC (International Rescue Committee), LATVIA. Another example is MASOC - The Association of Mechanical Engineering and Metalworking Industries. It was founded in 1994 as a voluntary non-government organization. It is essentially an industry information and consultancy center. Its aim is to facilitate industry development, enhance cooperation and promote professional development of industry specialists [15]. MASOC associates about 160 enterprises of the engineering and metalworking industry, as well as a number of related industries. In total, it provides employment to approximately 12 thousand people.

MASOC initiated the creation of the Latvian engineering and metalworking cluster. This is an industry cluster, since it associates the enterprises within the same industry. The cluster aims to enhance the competitiveness in the foreign markets, to promote innovations and to increase productivity. This cluster unites engineering and metalworking enterprises, educational institutions and other related entities. They participate in a number of activities in four areas:

- cooperation

- international liaison and export development

- education and research

- efficiency of production

At present, the number of technology parks in Latvia is insignificant compared to the other EU members. As an example, the numbers for Scandinavian technology parks are: Sweden - 30, Finland - 22, Norway -12 [16].

In the recent years, the so-called industrial parks have been developing in Latvia. An industrial park is an array of sites and services represented by factories where enterprises are provided with all the requisite conditions and have access to the up-to-date technologies for the production of state-of-the-art products. An industrial park provides enterprises with physical infrastructure (production facilities), administrative offices and warehouses, as well as the basic resources needed for production, such as electricity, gas, water, communication facilities, etc. In addition to that, it makes available a range of services and intellectual infrastructure, namely, managing organization, financial management, accounting and investment, project development and legal consultancy. As a matter of fact, an industrial park could fall under the category of business incubators. The main difference between a technology park and an industrial park is that the latter is not designed to work with deep technology companies. The clients of industrial parks are mostly light industry, food industry, engineering and metalworking enterprises. At present, there are 23 industrial parks in Latvia with the total area of 460 hectares. There are 10 more industrial park projects at different stages of development [2].

It is important to note that the development of industrial and technology parks does not play a defining role in the national policy unless the government provides support both on the national and the regional level. The development of technology parks should rely on support mechanisms offered by international organizations, and also on increased interest to such projects on the part of private capital. [17-19].

Another area where innovation activity is encouraged by the government is POLARIS process, connected with foreign investment raising. So far, foreign investment to Latvia has been due to an active support on the part of foreign investors, who took an interest or had already decided to invest in Latvia. In order to attract investment more actively and to plan and use the limited financial resources in a more effective way, a unique methodology of a task-oriented investment raising has been worked out. This methodology has been named POLARIS process. The main objectives of this process include: 
1. To define investment target sectors, the ones that would be the most viable in the near future and for which Latvia has adequate experience, infrastructure and markets. At present, target sectors include:

- metalworking, engineering, electronics;

- wood processing (sub-sectors with high added value);

- transit and logistics;

- information technologies;

- health care.

2. To sum up and update the available information related to target sectors of Latvian economy.

3. To come up with an offer to foreign investors with scientifically grounded projects, based on experience and strategic resources available in Latvia, such as natural resources, geographical position, labor etc. POLARIS process also involves a timely creation of foreign investor data base.

4. To coordinate cooperation between the government and municipal entities, representatives of the private sector (enterprises and industry associations) and the representatives of scientific circles (universities and research institutes). Such coordination should aim at the furtherance of new investment projects, timely problem resolution and monitoring ongoing projects. All these objectives are designed to develop the guidelines for the improvement of the business environment. The research into indirect methods of promoting innovation activity suggests that the government is making efforts to encourage innovation processes. These efforts, however, do not seem to bead equate.

\section{Conclusion}

In conclusion, it should be noted that engineering is a high added value industry and is important in any economy. It involves considerable knowledge and experience. In addition, it provides the other industries of the national economy with machinery, production systems, as well as the technologies and knowledge vital for such industries. The main objective in this area is the promotion of innovation activity, which is still at a low level in Latvia.

In order to refocus production and encourage it to create high added value goods, both the government and the private sector should do their best to enable investment inflow to this area, including investment from abroad. It is essential that Latvia should increase the role of private investment in the innovation process and create the conditions for the growth of productivity, which remains among the lowest in the European Union. The productivity of an employee in the EU is 32 euros per hour, while in Latvia it is 8.4 euros. Low productivity is a major challenge for the economy of Latvia. Labor shortage makes the increase in labor productivity and innovation activity in engineering vital for the national economy. According to the forecast provided by the Ministry of Economy, by 2020 Latvia will face labor shortage in such industries as mechanic engineering, metalworking, electrical engineering, electronics and automation and machinery engineering. The estimated labor shortage figure by 2020 is 6150 specialists, including 3.1 thousand workers, over 1.3 thousand engineers and $400 \mathrm{PhD}$ specialists in the area of engineering and metalworking [20]. This forecast means that it is only innovations that can help Latvian economy to cope with the problem of labor shortage, low productivity and the general lag in innovation activity [20]

\section{References}


1. LatvijasInvestīciju un attīstībasaǵgentūra (LIAA) http://www.liaa.gov.lv/lv/ uznemejdarbibas-veicinasana-un-inovacijas

2. Centrālā statistikas pārvalde (2016) http://www.csb.gov.lv/statistikastemas/inovacijas-galvenie-raditaji-30336.html

3. T. Odinokova, Economics. Ecology. Socium, 3 (2), 1 (2019)

4. R. Pukala, Engineering Management in Production and Services, 8, 3, 43 (2016)

5. V. Koval, G. Duginets, O. Plekhanova, A. Antonov, M. Petrova, Entrepreneurship and Sustainability, 6(4), 1922 (2019) http://doi.org/10.9770/jesi.2019.6.4(27)

6. Latvijas statistikas gada grāmata-2017 (Riga, 2018)

7. European Innovation Scoreboard (2018). https://www.interregeurope.eu/ policylearning/news/3806/european-innovation-scoreboard-2018/

8. N. Kurmanov, M. Petrova, S. Suleimenova, E3S Web of Conferences, 105, 04045 (2019) https://doi.org/10.1051/e3sconf/201910504045

9. R. Pukala, E3S Web of Conferences, 105, 04015 https://doi.org/10.1051/e3sconf/201910504015

10. R. Pukala, M. Petrova, E3S Web of Conferences, 105, 04034 (2019) https://doi.org/10.1051/e3sconf/201910504034

11. R. Vazov, Inovative Approaches to Insurance Company Cash Flow Management (contemporary theoretical aspects) (VUZF Publishing House "St. Grigorii Bogoslov, Sofia:, 2019)

12. T. Lazarova, V. Zhelyazkova, R. Vazov, Proceedings of International Conference for Entrepreneurship, Innovation and Regional Development ICEIRD 2015, University of Sheffield, 275 (2015)

13. M. Petrova, M. Tepavicharova, L. Dikova, E3S Web of Conferences Volume 41, 04017 (2018) https://doi.org/10.1051/e3sconf/20184104017

14. M. Petrova, I. Buzko, Yu Dyachenko, 17th International Scientific Conference ERDev, 1102 (2018) doi: 10.22616/ERDev2018.17.N170

15. Eurostate (2016) http://eurostat.ec.europa.eu/portal/page/portal/statistics/search database

16. I. Gryshova, M. Petrova, M. Tepavicharova, A. Diachenko, T. Gutsul, Entrepreneurship and Sustainability, $\quad 7(1), \quad 690 \quad$ (2019) http://doi.org/10.9770/jesi.2019.7.1(49)

17. A. Islamgaleyev, Innovation Processes in the context of Globalization of the World Economy: Challenges, Trends, Prospects (IPEG-2018) PRAGA (2018)

18. A. Islamgaleyev, Minzu University of China «Scientific research of the SCO countries: synergy and integration» June 29-30, 29 (2018)

19. A.H. Islamgaleyev, N.A. Uruzbayeva, Using a customer-oriented approach in sales management in the metal trading market of the Republic of Kazakhstan (Premier Publishing s.r.o., Vienna, 2018) http://doi.org/10.29013/IslamgaleyevA. UruzbayevaN.UC-OASMRK.184.2018

20. Ekonomikas ministrija. https://www.em.gov.lv/ 